\title{
The Implementation of Wakalah Contract by Multifinance Companies in Indonesia
}

\author{
Rachmawaty \\ Pamulang University, Jakarta, Indonesia \\ Tazkia Economics Islamic Collage University, Bogor, Indonesia \\ Email: dosen01925@unpam.ac.id \\ Kartika Dian Pandaya \\ University International of Semen Indonesia, Gresik, Indonesia \\ Email: tikapandaya@gmail.com \\ Alshamma Jamal Mohammed Al Azab \\ Master of Islamic Financial Practioner, INCEIF, Malaysia \\ Email: janajamal@gmail.com
}

\begin{abstract}
The purpose of this paper is to discuss Wakalah contract which is one of the Islamic banking contracts. Therefore, our main study is the implementation of Wakalah in Indonesia. Wakalah in Indonesia has special reference which is Multifinance company (MFC). MFC is an entity of non-bank financial institution conducts business activities to finance goods or services. Therefore, this research is going to discuss how Wakalah is practiced in Indonesia, where Islamic banks appoint MFC as an agent to do service for end user "customer" on behalf of the bank. Consequently, the objective of this paper is to discuss the implementation of Wakalah with Mudharabah and Wakalah with Murabahah by MFC in Indonesia in terms of operation, the potential risks that might be occur and shariah issues in terms of ownership and fee. However, there are particular areas in terms of operation that MFC should improve, as well as, banks have to be aware of its operational way of conducting agreement so banks mitigate any kind of risks or negligence.
\end{abstract}

Keywords: Wakalah, Multifinance company (MFC), Wakalah Mudharabah, Wakalah Murabahah.

\section{A. Introduction:}

Multifinance company is one of the main players in consumer finance sector in Indonesia. MFC offers services in terms of finance such as purchasing cars, motorcycles, furniture, etc. Thus, MFC enters into agreement with banks to conduct such services. According to Indonesia finance services, MFC is an entity of non-bank financial institutions which is specialized in conducting business activities and finance proving things or services such as leasing, factoring and business credit cards. MFC is regulated by The Financial Services Authority (OJK) which is a state institution in Indonesia. However, when it comes to Islamic 
banks in Indonesia, MFC is considered as an agent (Wakil), which acts on behalf of the bank and provides funds to consumers (End users) who are in need to get finance for their consumption. Moreover, in Indonesia, Islamic banks use two Islamic products with MFC for this kind of finance. The two products are Wakalah with Mudharabah and Wakalah with Murabahah. Furthermore, Wakalah which is an Islamic service, it is implemented in Indonesia by MFC. Despite, MFC is considered as an agent (Wakil), under Mudharabah contract becomes the debtor to the bank. While in Murabahah the End user is the debtor. Therefore, the objective of this research is to discuss the implementation of two types of Wakalah contract by MFC in Indonesia, which they are Wakalah with Mudharabah and Wakalah with Murabahah. The first part will explain the modus operandi for each contract. The second part will discuss the differences between Islamic banks and conventional in terms of Wakalah implementation dealing with MFC. The third part will discuss the potential risks as well as the shariah issues attached to Wakalah contract. And the last part will elaborate how MFC can mitigate the risk by giving recommendation and how it can make the implementation of Wakalah contract more into shariah compliance.

Thus, the methodology that have been used in this paper is qualitative method which consists of two ways. The first one is the literature review that will explain the implementation of Wakalah contract under Shariah principles and the implementation of Wakalah by MFC. The second one is interview that have been conducted with two management staff for two Islamic banks in Indonesia. Furthermore, the interviews' questions were about the implementation of Wakalah contract by MFC with Islamic banks which is conducting with Mudharabah and Murabahah.

\section{B. Literature Review}

In the literature review we want to explain about the meaning of wakalah, from the root word and the definition in the Islamic financial contracts. Wakalah also have four types according to the boundaries actof the agents towards the agreement. Wakalah contract commonly use with another contract when creating financing products, which for this paper we explain how wakalah can combine with Murabahah and Mudharabah. Wakalah with Murabahah and Wakalah with Mudharabah practically use in Indonesia for financing product by appointed an agent, which is MFC to do the tasks on behalf of the bank.

The term Wakalah or Wikalah literally means "preservation". According to the Hanafis, Wakalah is the delegation of one person (principal) for another (agent) to take his place in a known and permissible dealing (El-Gamal 1997/2003).Another definition for Wakalah, according to Saleem (2013), Wakalah 
is a contract in which a person who has complete legal capacity authorises another person to conclude a certain permissible contract on behalf of him.

Wakalah contract is a permissible contract based on the Quranic verse and practice of the Prophet S.A.W.

"For those who put their trust (mutawakkilun) should put their trust on Allah"(14:12).

Prophet S.A.W. allows the practice of Wakalah, and he himself practiced Wakalah in various transactions such as appointing Hakim bin Huzam and 'Urwah al Barqi to purchase sheep for sacrifice. Appoint AmribnUmayyah alDhamiri as an agent in to accept marriage of Umm Habibah. Appoint his companions to be the wakil to distribute payment for soldiers who were going to the war.According to Saleem (2013), he says that the main purpose for agency contract is to facilitate economic exchange between a principal and third party who have some difficulties condition such as time, distance, number of transaction when the principal can't act personally.

Wakalah must be based on four pillars; principal (muwakkil), an agent (wakil), subject-matter of an agency, and the agreement (offering and acceptance) (Saleem, 2013).

According to Bank Negara Malaysia (2016), Wakalah are binding with four following situations; i.) Wakalah contract involves rights of third party; ii.) Wakalah contract involves a fee (Wakalah bi al-ujrah) need to pay to the agent; iii.) Agents has commenced the work that he has been authorized to do and discontinuance of the work would cause the principal or the agent to suffer damages; iv.) Principal and the agent have agreed not to terminate the Wakalah contract within a specified time.

Wakalah divided into four type base on the boundaries an agent can act behalf on the principal, and according toSaleem (2013) the four types of Wakalah are: i.) Particular agency (al Wakalah al-khassah) : an agency contract that appointing agent to do for only certain known transaction; ii.) General agency (al Wakalah al-'aammah): an agency contract which the agent have full authority and power to act and perform a series of transaction on behalf of principal; iii.)Unrestricted agency (Wakalahmutlaqah): an agency contract in which the agent to perform a task without any specific restriction or condition; iv.) Restricted agency (Wakalahmuqayyadah): an agency contract in which the agent to perform a task with specific restriction or condition.

Usually Wakalah is not like working as single contract, it should be combined with another Islamic finance product such as Murabahah. There is no 
definition for such combination of contracts in fiqh literature. However, the combination of contracts (ijtima al-uqud) may defined as an agreement between two or more parties to put together two or more contracts with different features and legal consequences to achieve a desired viable transaction. In this case, all obligations and legal consequences arising from the combined contracts are to realize as one single obligation (Hammad, 1998).

Combined contracts should be giving new advantages and can be applicable for financing products.Combined contracts must fulfil certain conditions to make it shariah compliance, which are; i.)Must not violate the nature or any of the included contracts; ii.)Must not lead to Riba; iii.)Must not conflict with sacred texts.(Kahf, 2015).

According Kahf(2015) Wakalah arrangement can be applied for many kind modus operandi including transaction, selling, buying, investing, etc. There will be some example product when we apply it into Islamic banking product and transaction, such as: a.) Deposit taking based on Wakalah whereby the bank acts as wakil or agent to manage customers' investment; b.) Letter of credit (LC) based on Wakalah whereby the bank acts as wakil or agent to make payment to the negotiating bank; c.) Private banking investment whereby the bank acts as wakil or agent to manage investment of the customer (wealth management); d.)In Murabahah financing whereby the bank acts as wakil or agent to buy the asset from the vendor and subsequently sell it to the customer; e.)In tawarruq financing whereby the bank acts as wakil or agent to sell and buy the commodity (through the brokers) on behalf of the customer.

As the objective of this paper is explaining the practice ofWakalah contract in Indonesia. The agent that is appointed to do the tasks on behalf of the bank is MFC (Multifinance Company). According to Indonesia Financial Services Authority No. 29/POJK.05/2014, Multifinance Company is an entity non-bank financial institutions specializing in conducting business activities to finance proving things or services such as: leasing, factoring, business credit cards and consumer finance as a credit or car.Therefore, there are two types of Wakalah contract in Indonesia, which are:

1. Wakalahwith Mudharabah for financing, the bank appointed an agent (MFC) to give financing facility to end users. The money is from the bank and the MFC will finance the end users who have been selected by certain criteria which agreed by MFC and bank, usually the financing for end users is working capital. These scheme of financing the money transferred based on executing way where all the money give to the MFC first, so the debtor is MFC. 
2. Wakalahwith Murabahah for financing, where the bank appointed an agent (MFC) to do some job on behalf of the bank towards end users when the end users want to buy something. For example, house or car. In this scheme, the money will be transferred based on channelling way goes straight to the individual end user so the debtor is individual end user, and MFC act as an agent to the bank.

\section{Findings:Wakalah in Islamic Banking Indonesia's Financing}

There are two type of Wakalah contracts that are used among banks, MFC and end users in Islamic Banking Indonesia's financing. They are Wakalahwith Mudharabah contract and Wakalah with Murabahah contract. The difference between them will be elaborated more in modus operandi to understand the risk embedded and the shariah issues that might be encountered.

In Wakalah with Mudharabah, the parties involved consist of three parties. First is end user which is personal/ individual whom receive finance from MFC, second is MFC which will be bank's debtor and third is bank as the fund provider. Modus operandi of Wakalah with Mudharabahtake in places when MFC will conduct Wakalahwith Mudharabah contract with bank. The following stepsthen bank will invest the money to finance a particular product to the end user (debtors). Bank will set up the criteria of end user such as personal financing or small working capital for end user. Bank will do the disbursement to MFC's account and the MFC will do the analysis of the end users qualification, maintaining the facility and collecting end user's payment before MFC pay to the bank. In case of default, MFC will take the responsibility of doing the payment. However, the one who will become debtor in the bank statement and will be recorded as debtor in Information Debtor System in Central Bank is MFC in Wakalahwith Mudharabah contract.

Fig.1. Scheme of Wakalah with Mudharabah contract - bank's debtor is MFC.

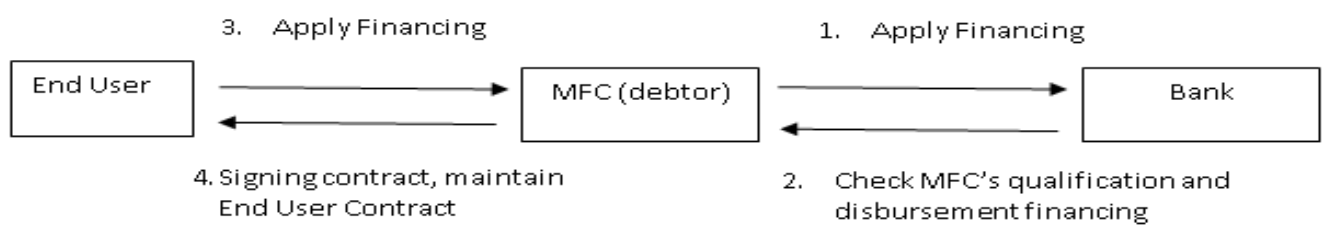

Source: Author's own based on interviews made.

In Wakalah with Murabahah contract, the parties involved consist of fourth parties. First is end user which is personal/ individual whom receive finance 
from bank and become bank's debtor, second is MFC which will be bank's agent, third is bank as the fund provider and the fourth is dealer of car/motorcycle or the one who sell commodity. Modus Operandi of Wakalah with Murabahahtake in place when bank gives maximum limit of financing to MFC. In the following steps, MFC is responsible on behalf of the bank to find potential end user (debtors). MFC Collects document requirement for applying financing, analysing end user (debtors) based on risk acceptance criteria that was set up by bank such as what the type of car, the minimum financing to value. If the potential debtors are eligible to get financing then MFC will inform the bank through system between bank and MFC, the system will check the usage of financing limit and whether the debtor criteria are passed bank's requirement. When the criteria of the end user are being accepted, the bank will transfer the financing fund to MFC. Immediately, MFC will send purchase order to dealer and signing Murabahah contract with end user (debtors) on behalf of bank. In Indonesia, in Murabahah sometimes the vehicle is not in the stock yet, end user must wait for the vehicle, but it is allowed for end user to sign Murabahah contract. However, after the vehicle is received by end user, MFC will disbursement money to dealer.

Fig.2. Scheme of Wakalah with Murabahah contract - bank's debtor is end user

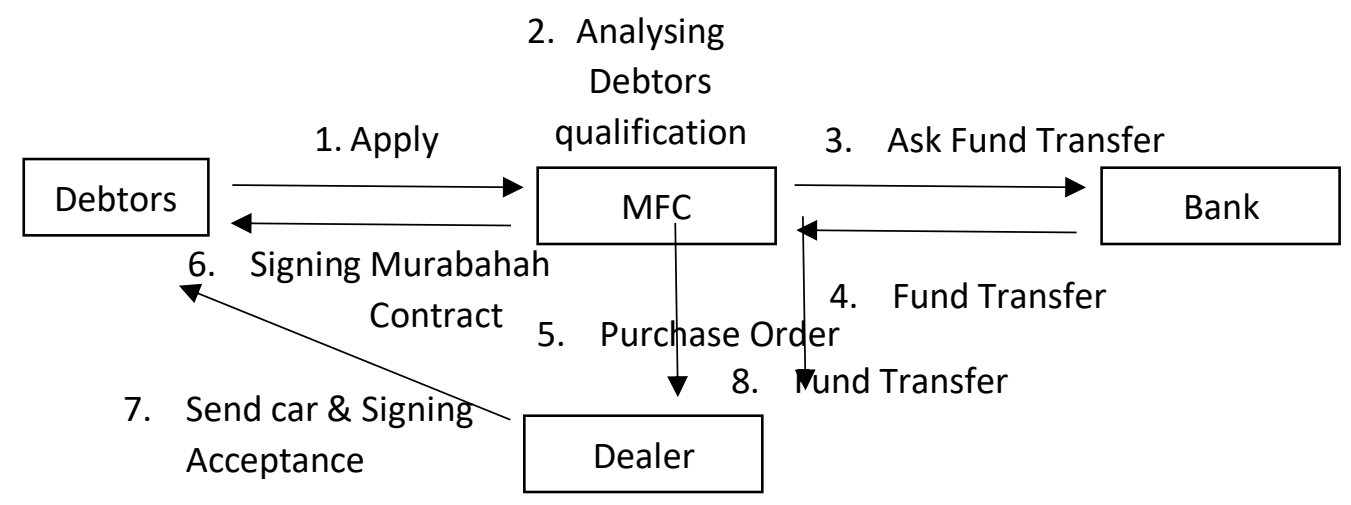

Source: Author's own based on interviews made.

There is preference of using Wakalahwith Murabahah contract compared to Wakalah with Mudharabah contract for Bank. Although Wakalahwith Murabahah contract is riskier for bank than Wakalahwith Mudharabah contract, there are some advantages for bank of using Wakalahwith Murabahah contract. First, In Wakalahwith Murabahah contract from management portfolio risk's perceptive, having portfolio which distributed for many debtors (end users) is much better than concentrating in one debtor (MFC). Second in Wakalahwith Murabahah contract, the risk of weighted asset for financing with debtor (end 
user) isless than the risk of weighted asset for financing with debtor (MFC), thus one of bank's strategies is to minimize their capital adequacy ratio to decrease provision and get more net profit, therefore bank will choose portfolio with less weighted asset. Third by using Wakalah withMurabahah contract with end user will give possibility for bank to increase the consumer segment or micro financing. While on the other perceptive, MFC will prefer to use Wakalah withMurabahah contract if there is no issue in system technology to record and reconciliation the end user data between MFC's recording and bank's recording specially in payment and information of end user as well as the status of legal ownership documentation.

\section{Comparison between Islamic Bank and Conventional Bank in the way of implementing in Wakalah contract.}

The implementation of wakalah product in Islamic bank as the alternative product that can give more contribution to increase bank's financing portfolio. However, if we compare the nature of business of this particular financing between Islamic bank and conventional bank, we will find some flavour that conventional bank as shown in below table.

Table 1: The comparison of using Wakalah between Islamic Bank \& Conventional

\begin{tabular}{|c|l|l|}
\hline \multicolumn{1}{|c|}{ Items } & \multicolumn{1}{|c|}{ Islamic Bank } & \multicolumn{1}{c|}{ Conventional Bank } \\
\hline Joint financing & It's not allowed & $\begin{array}{l}\text { It's allowed. } \\
\text { For example: 90\% financing } \\
\text { from bank while 10\% from } \\
\text { MFC. }\end{array}$ \\
\hline Number of End users & $\begin{array}{l}\text { Not much because of the } \\
\text { restrictions attached to } \\
\text { contracts }\end{array}$ & $\begin{array}{l}\text { A lot because of facilitating } \\
\text { the consequences of } \\
\text { contracts }\end{array}$ \\
\hline Taking over & $\begin{array}{l}\text { It is not allowed to take-over } \\
\text { MFC's portfolio or } \\
\text { refinancing end user } \\
\text { without end user sign } \\
\text { contract. }\end{array}$ & $\begin{array}{l}\text { It is common } \\
\text { forconventional bank to take } \\
\text { over MFC's portfolio or } \\
\text { refinancing end user. }\end{array}$ \\
\hline Fee & $\begin{array}{l}\text { The spread between interest } \\
\text { rate or profit price that multi } \\
\text { financing give to end user } \\
\text { and get from bank }\end{array}$ & $\begin{array}{l}\text { the spread between interest } \\
\text { rate or profit price that multi } \\
\text { financing give to end user } \\
\text { and get from bank }\end{array}$ \\
\hline
\end{tabular}

Bank. 
Source: Author's own based on interviews made.

\section{E. Risk taken by Banks in Wakalah with Murabahah or Mudharabah:}

There will be risk that may arise when bank appoints MFC as an agent to do some finance activities. There are two kinds of risk that embedded in Wakalah scheme and should be mitigated by bank. First is credit risk, which give impact to the quality of bank's financing portfolio. The credit risk is come from the probability double financing of end user when ask disbursement financing from bank while at the same time MFC also have ask disbursement from another bank that has the same financing contract, the double financing could be happen if bank did not perform 100\% information debtor checking before disbursement. Sometime bank does not do $100 \%$ information debtor checking before disbursement because bank has the obligation and for competitive reasons. Bank should give respond in 1 day for MFC, while it is taking time for bank to process and check information about the debtor in central bank system. Another credit risk that may rise is MFC doesn't perform its function as agent to collect payment. MFC has an obligation to collect the money from the debtor, because the debtor is based on its recommendation. Sometimes MFC will not be performing well in collecting payment from end user. In case of default, for Wakalahwith Murabahah the NPF (non-performing financing) only for the end user because it is the debtor. While, in Wakalahwith Mudharabah the NPF affects MFC's name because it is the debtor for bank.

Operational Risk in this scheme because bank points MFC as an agent to conduct marketing, analysing, keeping legal document and collecting payment of end user. The imprudently of MFC to conduct analysing end user in acquisition part such as the weakness of income verification and end user information can be the operational risk for bank. Another operational risk is about safekeeping the legal ownership documents and original contract of end user, where most of the banks prefer to be kept and maintained by MFC, because of efficiency and limitation of custody. In Indonesia, there is a need to renew the duration of vehicle licence, if the ownership document is kept by the bank, the bank must release information letter which will be additional operational job it. Therefore, Banks ask MFC to keep the relative documentation of end user contract such as original ownership document. In this case, there is a possibility of losing the document because of improper way of safekeeping by MFC.

\section{F. Shariah issues in Wakalah with Mudharabah and Wakalah with Murabahah}

According to our study for Wakalah with Mudharabah contract and Wakalah with Murabahah contract, there are some shariah issues that we want to 
explore. Shariah issues in Wakalah with Mudharabah and Wakalah with Murabahah are different. The issues will be clearly explainedas below:

Shariah issues inWakalahwith Mudharabah contract is about the feethat based on profit sharing ratio from profit. The statement in the agreement only about how much profit sharing for the MFC and how much profit sharing for bank. The price rate that MFC will give to the end users will not be mentioned in the agreement between MFC and bank.

In the Wakalahwith Murabahah contract there are more shariah issues that occur in the transactions. The issues are as below:

First is about ownership of subject matter in Murabahah contracts. When the transaction happens, sometime the subject matter (house or vehicle) is not in the stock yet but it is ordered. However, for end user they will sign Murabahah contract and pay down payment even if the vehicle is not in stock yet. The end user will choose what they want according to the pricelist from MFC. This case usually happens in short time less than a month. The underlying of Murabahah contract is the purchase order document from the dealer.

Second issue is about reimbursement payment to the MFC. In Murabahah contract the payment for the subject matter should be from the buyer. In this case is from bank (principle). However, sometimes underWakalahwith Murabahahcontract, MFC pays first to dealer,then it will ask for reimbursement from the bank afterwards.

Third issueunderWakalah with Murabahah contract is the fee. The fee isbased on spread of the percentage of profit margin for the bank which has been agreed between the bank and the MFC. For example, if the profit margin is $10 \%$, the bank will get $8 \%$ and the MFC will get $2 \%$. Meaning MFC give the end users $2 \%$ higher than the bank financing. But some banks will not mention about the spread.

\section{G. Recommendations for Risk and Shariah Issues}

The recommendations in this paper will be about both for risk and Shariah issues. The recommendations are based on the literature and the business practice. Risks that banks may face in Wakalah with Murabahah or Mudharabah consist of 2 types, which they are credit risk and operational risk. Bank can mitigate credit risk bysetting up criteria what kind of MFC thatwill have agreement with it and due diligence how well MFC manages its portfolio. Bank can have additional agreement with MFC to cap the worst collection of payment performance, for example, if quality of end user portfolio more than $2 \%$ is nonperforming financing or end user default to pay payment for more than 3 months than MFC should buy back from the respective bad end user portfolio. Likewise, 
for operational risk bank can mitigate it through performing post disbursement quality assurance, such as monitoring closely MFC performance, doing periodically sampling such as checking information of end user in central bank system, visiting end user and dealer on the spot and calling end user to recheck information that MFC has given. To make sure that MFC keeps the end user original legal ownership, bank can do checking the existences of original legal ownership in MFC's custody.

The shariah issue for Wakalah with Mudharabah using profit sharing ratio as the base to count fee for MFC, according to El-Gamal (1997/2003) the fee generated by MFC using profit sharing ratio is allowed. Even though the agreement doesn't state the profit margin that MFC gets from the end user, this is not a problem. However, the profit margin should be same or higher than what MFC should pay to the bank. So, the bank and MFC will not face any loss. And that is permissible in Shariah and Wakalah transaction become valid. Therefore, for more transparency we recommend that bank should give boundaries about the profit margin between MFC and the end user in the agreement.

As for Wakalah with Murabahah the first shariah issue is about ownership of subject matter.According to Salem (2013), in Murabahah contract the first contract between dealer and MFC should be valid and the object is completely owned by its seller. In this case, the end user sign the agreement before the subject matter is available, so the contract will be invalid. Therefore, we recommend that the MFC take Wa'ad from the end user to purchase the subject matter when it's ready or delivered because they will not sign Murabahah contract unless the subject matter exist. Therefore, end user pays down payment then the purchasing order for the subject matter will be issued and the Murabahah contract will take place when the subject matter exist and ready.

The second shariah issue is aboutthe reimbursement payment. MFC can pay first to dealer and asking reimbursement from the bank afterwards, if it has been stated that MFC can use its money first then the bank reimburse to MFC in the agreement between MFC and bank.

Third issue in Wakalah with Murabahah is about the fee generated by MCF is based on spread of the percentage of profit margin.According to El-Gamal (1997/2003), the fee for Wakalahcan be given either by state the nominal, the profit sharing ratio, or the spread margin depends on the type of Wakalah agreement. But according to Hanafi and Al-TahawiEl-Gamal (1997/2003), they ruled that agent may only sell for a price that is legal tender or close to the market price so the requirement should be within $5 \%$ of the going market value. We recommend that the agreement between the bank and MFC should have 
limitations about the selling price in the agreement in case that MFC does not mention their fee directly to the price in the agreement.

\section{H. Conclusion:}

Based on our research, MFC plays a primary role in terms of consumer finance in Indonesia. It is an entity of non-bank financial institution that is regulated by The Financial authority in Indonesia. Where MFC provides financial services to end user by entering into agreement with banks to get the fund.Nevertheless, regarding Islamic banks MFC plays the role of agency and consider as (Wakil) conducting two kinds of contracts which are Mudharabah and Murabahah. Therefore, based on the literature review and findings, the implementation of Wakalah with Mudharabah and Wakalah with Murabaha by MFC is not efficient enough in terms ofoperation, which may lead banks to face credit and operation risks due to default or negligence. Therefore, MFC should improve their way of operation with banks so the transactions of Wakalah with Mudharabah and Wakalah with Murabahah become more efficient and trusted. However, banks can sit some criteria and conditions in terms of dealing with MFC as well as the agreement between banks and MFC should be clear and the fee of MFC should be mentioned as well.Hence, we can conclude that the implementation of Wakalah contract in Indonesia does not have any crucial issue which could be against the shariah rules and principles.

\section{References:}

Bank Negara Malaysia. (2013): 'Wakalah (Shariah Requirements and Optional Practices)'.

Bank Negara Malaysia. (2015): 'Wakalah- Concept Paper', Central Bank of Malaysia.

Hammad, N. (1998). Ijtima' al-uqud al-Muta'didah fi SafaqahWahida fi al-Fiqh al-Islami.A'mal al-Nadwah al-Fiqhiyyah al-Khamisa. Kuwait: Kuwait Finance House.

Iqbal, M., Ahmed, A., \& Khan, T. (1998): 'Challenging Facing Islamic Banking', Islamic Development Bank \& Islamic Research and Training Institute.

Kammer, A., Norat, M., Pinon, M., Prasad, A., Towe, C., Zridane, Z., \& IMF Ataff Team. (2015): 'Islamic Finance: Opportunities, Challenges, and Policy Option. International Monetary Fund.

Kahf, Monzer. (1975).Islamic FinanceContracts.United State: Createspace Independent Publishing Platform. 
Mutiara DS, Zakaria,B, Zahri H (2016): “History of Islamic Bank in Indonesia: Issues Behind Its Establishment". International Journal of Finance and Banking Research 2016; 2(5): 178-184

Nyazee, IAK. (2002).Islamic Law of Business Organization. Kuala Lumpur.Malaysia:The Other Press Malaysia edition. 1st published by the international institute of Islamic thought Islamabad.

OtoritasJasaKeuanganRepublik Indonesia. (2014): Penyelenggaraan Usaha Perusahaan Keuangan No. 29/POJK.05/2014

Sarker, A.A.: 'Islamic Banking contracts, agency Problems and The Theory of The Islamic Firms', International Journal of The Financial Services Vol1. No2.

Saleem, Yusuf. (2013). An Introduction to the Theoretical Foundation of Islamic Transaction (second revised edition). Singapore: Wiley Finance.

El-Gamal, Mohmoud A. (2003).Financial Transaction in Islamic Jurisprudence. (WahbahZuhayli, Trans.). Damskus, Syria: Dar Al Fikr (original work published 1997). 